\title{
Ann Arbor Stage IV Noncutaneous Childhood Anaplastic Large Cell Lymphoma
}

National Cancer Institute

\section{Source}

National Cancer Institute. Ann Arbor Stage IV Noncutaneous Childhood Anaplastic Large

Cell Lymphoma. NCI Thesaurus. Code C115032.

Ann Arbor Classification: Stage IV: Diffuse or disseminated involvement of one or more extralymphatic organs, with or without associated lymph node involvement; or isolated extralymphatic organ involvement in the absence of adjacent regional lymph node involvement, but in conjunction with disease in distant site(s); or any involvement of the liver or bone marrow, lungs (other than by direct extension from another site), or cerebrospinal fluid. 